\title{
POOR EFFICACY OF THE MOST COMMONLY USED ANTHELMINTICS IN SPORT HORSE NEMATODES IN MOROCCO IN RELATION TO RESISTANCE
}

\author{
ZOUITEN H.*, BERRAG B.**, OUKESSOU M.**, SADAK A.* \& CABARET J.***
}

\section{Summary:}

Sport and leisure horses in Morocco are treated with several anthelmintics, organophosphates (dichlorvos), benzimidazoles (mostly thiabendazole) or tetrahydropyrimidines (mostly pyrantel pamoate) against nematodes. We studied three horse stables in Rabat, one in Meknes and one in Bouznika. Two of the Rabat and Bouznika stables had introduced a large number of horses from countries (Argentina or Europe) where resistance to benzimidazoles is frequent, whereas the Meknes stud farm remained without foreign introduction. The number of treatments was not very frequent (twice a year in adult horses) but the same anthelmintics were used repeatedly. No resistance to dichlorvos was detected whereas benzimidazole and pyrantel pamoate resistances were detected for the first time in African horses, outside South Africa.

KEY WORDS : anthelmintic, horse, nematode, Morocco, resistance.
Résumé : EFFICACITÉ RÉDUITE DES ANTHELMINTHIQUES LES PLUS UTILISÉS CHeZ le cheval au Maroc en relation avec la Résistance

Les chevaux de sport et de loisirs au Maroc sont traités pour les infections par les nématodes avec plusieurs anthelminthiques, des organophosphorés (dichlorvos), des benzimidazoles (principalement le thiabendazole) ou des tétrahydropyrimidines (principalement le pamoate de pyrantel). Nous avons étudié trois écuries à Rabat, une à Meknes et une autre à Bouznika. Deux des écuries de Rabat et celle de Bouznika ont introduit des chevaux en grand nombre d'Argentine ou d'Europe, qui sont des régions avec des résistances très fréquentes, alors que le site de Meknes restait sans introduction. Le nombre de traitements n'était pas très élevé (deux par an chez les adultes), mais les mêmes molécules ont été utilisées de manière répétitive au sein de chaque écurie. Aucune résistance au dichlorvos n'a été enregistrée, mais par contre des résistances aux benzimidazoles ou au pamoate de pyrantel ont été mises en évidence pour la première fois chez des chevaux africains (hors Afrique du Sud).

MOTS CLÉS : anthelminthique, cheval, nématode, Maroc, résistance.

\section{INTRODUCTION}

H orses are important in Morocco, as a working or a leisure animal (360.000 heads in 2001). The internal parasitic diseases are frequent in working donkeys and horses of Morocco (Pandey \& Dakkak, 1979; Cabaret \& Pandey 1980; Pandey \& Cabaret, 1993). Horses harbour small and large strongyles, and other nematodes such as Habronema sp. or Trichostrongylus axei, and insect larvae, Gasterophilus spp. (Ouhelli et al., 1979). In Morocco, small strongyles are considered as playing an important role in severe diarrhoea and colitis (Berrag \& El Kohen, 1999). Large strongyles were a major cause of diseases in horses and frequent treatments programs were implemented in

\footnotetext{
* Faculté des Sciences, Département de Biologie, Avenue Ibn Battouta, BP 1014, Rabat, Maroc.

** Institut Agronomique et Vétérinaire Hassan II, Département de Parasitologie, BP 6202, Rabat-Instituts, Rabat, Maroc.

**:* Institut Agronomique et Vétérinaire Hassan II, Département de Physiologie et Thérapeutique, BP 6202, Rabat-Instituts, Rabat, Maroc. ***** INRA, Bio-Agresseurs Santé Environnement, 37380 Nouzilly France.

Correspondence: jacques.cabaret@tours.inra.fr
}

order to control infection; it resulted in an increase of small strongyles which were considered as much less pathogenic than large strongyles (Kaplan, 2002). The first reports of thiabendazole resistance in the cyathostomes (= small strongyles) were recorded by Drudge \& Lyons, 1965; later, it has been extensively reported in many countries (Lyons et al., 1999). Resistance to pyrantel was reported only in recent years although it has been used since the 1970's, and mostly in places were daily feeding with pyrantel is practised (Kaplan, 2002). Resistance to organophosphate is not documented in horse nematodes. The majority of resistance studies are based on the faecal egg reduction test (FECRT) and Bauer et al. (1986) stated that a reduction of less than $80 \%$ after treatment was indicative of resistance. Resistance is then a common feature in horse small strongyles in South Africa (Matthee et al., 2000), USA (Drudge \& Elam, 1961; Wood et al., 1998), Brazil (Pereira et al., 1991), Denmark (Bjorn et al., 1991), Australia (Waller, 1993), Belgium (Geerts, 1995) and Ukraine (Borgsteede et al., 1996) among others.

The sport and leisure horses in Morocco benefit from anthelmintic treatments, some of them are imported from countries where prevalence of resistance is high, 


\begin{tabular}{|c|c|c|c|c|}
\hline Site & Breeds and origins & Activity & $\begin{array}{l}\text { Previous use } \\
\text { of the anthelmintics } \\
\text { in the lest ten years }\end{array}$ & $\begin{array}{l}\text { Tested } \\
\text { anthelmintics } \\
\text { for efficacy } \\
\text { in present study }\end{array}$ \\
\hline Raf-Unit 1 & $\begin{array}{l}\text { English, Argentina, Arab, and Barb } \\
\text { thoroughbreds and their crosses } \\
\text { (introduction from Europe and } \\
\text { Argentina in } 1996 \text { and before) }\end{array}$ & $\begin{array}{l}\text { Polo, Escort, Fantasia, Racing } \\
\text { competition }\end{array}$ & $\begin{array}{l}\text { Dichlorvos } 53 \% \\
\text { Thiabendazole } 29 \% \\
\text { Oxibendazole } 18 \%\end{array}$ & Dichlorvos \\
\hline Raf-Unit 2 & $\begin{array}{l}\text { Argentina, Holland, Barb thorough- } \\
\text { breds and their crosses (introduction } \\
\text { from Europe and Argentina in } \\
1996 \text { and before) }\end{array}$ & $\begin{array}{l}\text { Polo, Escort, Fantasia, Racing } \\
\text { competition }\end{array}$ & $\begin{array}{l}\text { Thiabendazole } 68 \% \\
\text { Piperazine } 11 \% \\
\text { Dichlorvos } 11 \% \\
\text { Oxibendazole } 8 \% \\
\text { Mebendazole } 2 \%\end{array}$ & $\begin{array}{l}\text { Thiabendazole } \\
\text { Dichlorvos }\end{array}$ \\
\hline El Harka & $\begin{array}{l}\text { Arab-Barb, Arab, English thorough- } \\
\text { breds }\end{array}$ & Riding school & $\begin{array}{l}\text { Pyrantel pamoate } 60 \% \\
\text { Oxibendazole } 40 \%\end{array}$ & Pyrantel pamoate \\
\hline $\begin{array}{l}\text { Bouznika } \\
\text { Stud-farm }\end{array}$ & $\begin{array}{l}\text { English and Arab thoroughbreds } \\
\text { (massive importation from Europe } \\
\text { in 1994) }\end{array}$ & $\begin{array}{l}\text { Exchange of studs between } \\
\text { stables }\end{array}$ & $\begin{array}{l}\text { Pyrantel pamoate } 50 \% \\
\text { Dichlorvos } 40 \% \\
\text { Oxibendazole } 10 \%\end{array}$ & Pyrantel pamoate \\
\hline $\begin{array}{l}\text { Meknes } \\
\text { Stud-farm }\end{array}$ & $\begin{array}{l}\text { Barb and Arab thoroughbred and } \\
\text { their crosses (no importation from } \\
\text { other countries) }\end{array}$ & $\begin{array}{l}\text { Exchange of studs between } \\
\text { stables }\end{array}$ & Pyrantel pamoate $100 \%$ & Pyrantel pamoate \\
\hline
\end{tabular}

Table I. - Characteristics of horse stables studied in Morocco.

and they may distribute resistance genes along their movements from one racing place, polo competition, or through mouvements of studs. According to pro and cons for acquiring resistance (Silvestre et al., 2002) these horses are good candidates for harbouring resistant cyasthostomes. The same family of anthelmintics are apparently repeatedly used, which would be a major pro for selection of resistance. We recorded the main anthelmintics used in different leisure or stud horse farms from Morocco and we checked their efficacy using faecal egg counts or in vitro tests and tentatively deduced the resistance status of nematode communities.

\section{MATERIALS AND METHODS}

S everal sites in Morocco were investigated in Rabat (Raf-1, Raf-2, El Harka), one in Meknes and one in Bouznika (Table I) from 1999 to 2002. Only adult horses were studied.

The efficacy was first evaluated on faecal egg counts (FEC) using McMaster technique (one egg seen = 50 eggs per gram or EPG, Manual of veterinary parasitology laboratory techniques, 1986) and the most used anthelmintic(s) during the last 10 years was (were) tested (Table I). The decrease of the FEC (FECRT faecal egg count reduction test in faeces) was evaluated on day of treatment (arithmetic average T1) and 10-12 days after (arithmetic average T2). The reduction was calculated as $((\mathrm{T} 1-\mathrm{T} 2) / \mathrm{T} 1) \times 100$. According to Sangster, 1996 or Bauer et al., 1986, resistance is suspected when FECRT < $80 \%$ whereas Coles et al., 1992 propose FECRT $<90 \%$. The faecal individual reduction
(Cabaret \& Berrag, 2004) and bootstrap confidence interval were also calculated using the Resivers program (Cabaret et al., 2001). The evaluation of resistance was also done on egg development for benzimidazole (using thiabendazole at various concentrations: Coles et al., 1992) and motility of third stage larvae for pyrantel pamoate based on a similar test provided by Coles et al., 1992, replacing development by motility and thiabendazole by pyrantel pamoate. The evaluation of confidence interval at $95 \%$ of the LD50 (lethal dose on eggs) or ID50 (immobilizing dose of $50 \%$ of larvae) was performed with the probit program (Raymond, 1985).

\section{RESULTS}

T The number of treatments was twice a year for adults and three times a year for yearlings in all the sites. Nematodes were mostly cyathostomes (more than $80 \%$ of larvae) as evaluated in Raf-2.

\begin{tabular}{|c|c|c|c|c|}
\hline Sites & $\begin{array}{c}\text { No } \\
\text { of horses }\end{array}$ & $\begin{array}{c}\text { Eggs } \\
\text { per gram } \\
\text { D0 }\end{array}$ & $\begin{array}{c}\text { Eggs } \\
\text { per gram } \\
\text { D10 }\end{array}$ & $\begin{array}{c}\text { FECR } \\
(\%)\end{array}$ \\
\hline Raf-Unit 1 & 30 & $\begin{array}{c}945^{*} \\
(0-6,150)^{* *}\end{array}$ & $\begin{array}{c}5 \\
(0-150)\end{array}$ & 99.5 \\
\hline Raf-Unit 2 & 8 & $\begin{array}{c}970 \\
(1,350-6,050)\end{array}$ & 0 & 100 \\
\hline
\end{tabular}

* arithmetic average and ** range.

Table II. - Dichlorvos faecal egg count reduction test (FECR 10 days after treatment) in horses from two sites (33 $\mathrm{mg} / \mathrm{kg}$ body weight) (1999). 
Efficacy of dichlorvos (Table II)

The efficacy of dichlorvos (Equigard ${ }^{\circledR}$ ) remained high, and no resistance was evidenced in the two horse stables we investigated.

. Efficacy of pyrantel pamoate (Table III)

The efficacy of pyrantel pamoate (Strongid ${ }^{\circledR}$ ) was low (69) or 72 reduction of FEC) and the in vitro test on motility of larvae (the values were three times higher than in a susceptible community) corroborated that the Meknes stud farm harboured a resistant worm community.

. Efficacy of thiabendazole (Tables IV and V)

The efficacy thiabendazole (Thibenzole ${ }^{\circledR}$ ) was low (32$53 \%$ on average value) in the five stables of Raf- 2 as

\begin{tabular}{|c|c|c|c|c|}
\hline Sites & No of horses & $\begin{array}{c}\text { Eggs per gram } \\
\text { D0 }\end{array}$ & $\begin{array}{c}\text { Eggs per gram } \\
\text { D10 }\end{array}$ & $\begin{array}{l}\text { and individual based estimations } \\
\left.\text { and } 95 \% \text { confidence interval }{ }^{* *}\right) \\
\left.\text { (paralysis dosis } \mu \mathrm{g} / \mathrm{mL}^{* * * *}\right)\end{array}$ \\
\hline Bouznika & 6 & $\begin{array}{c}175^{*} \\
(50-500)^{* * *}\end{array}$ & $\begin{array}{c}8 \\
(0-50)\end{array}$ & $\begin{array}{c}\text { 95* }(97: 94-99)^{* * *} \\
\text { (Not done) }\end{array}$ \\
\hline Meknes & 10 & $\begin{array}{c}970 \\
(300-3,200)\end{array}$ & $\begin{array}{c}300 \\
(0-950)\end{array}$ & $\begin{array}{c}69(72: 62-82) \\
(0.95: 0.48-2.02)\end{array}$ \\
\hline Rabat (El Harka) & 10 & $\begin{array}{c}725 \\
(300-2,650)\end{array}$ & $\begin{array}{c}60 \\
(0-150)\end{array}$ & $\begin{array}{l}92(88: 78-98) \\
(0.34: 0.25-0.42)\end{array}$ \\
\hline
\end{tabular}

* arithmetic average and ** range.

Table III. - Faecal egg count reduction test (FECR 10 days after treatment) with pyrantel pamoate in horses from three sites $(6.6 \mathrm{mg} / \mathrm{kg}$ body weight).

\begin{tabular}{|c|c|c|c|}
\hline Stable & $\begin{array}{c}\text { Eggs per gram } \\
\text { D0 }\end{array}$ & $\begin{array}{l}\text { Eggs per gram } \\
\text { D12 }\end{array}$ & $\begin{array}{c}\text { FECR (\%, average or individually } \\
\text { based-with } 95 \% \\
\text { confidence interval) }\end{array}$ \\
\hline $\begin{array}{l}\mathrm{N}^{\circ} 1(\mathrm{n}=20) \\
\text { Argentina thoroughbreds }\end{array}$ & $\begin{array}{c}1,952^{*} \\
(50-5,500)^{* *}\end{array}$ & $\begin{array}{c}1,140 \\
(0-3,850)\end{array}$ & $\begin{array}{c}42 \\
37(19-55)\end{array}$ \\
\hline $\begin{array}{l}\qquad \mathrm{N}^{\circ} 2(\mathrm{n}=8) \\
\text { Mostly English thoroughbreds } \\
\text { and Anglo-arab crosses }\end{array}$ & $\begin{array}{c}594 \\
(0-1,750)\end{array}$ & $\begin{array}{c}281 \\
(0-900)\end{array}$ & $\begin{array}{c}53 \\
64(45-83)\end{array}$ \\
\hline $\begin{array}{l}\mathrm{N}^{\circ} 3(\mathrm{n}=25) \\
\text { European thoroughbreds }\end{array}$ & $\begin{array}{c}2393 \\
(500-8,850)\end{array}$ & $\begin{array}{c}1,412 \\
(0-6,950)\end{array}$ & $\begin{array}{c}41 \% \\
22(9-41)\end{array}$ \\
\hline $\begin{array}{c}\mathrm{N}^{\circ} 4(\mathrm{n}=20) \\
\text { Arab-Barb crosses }\end{array}$ & $\begin{array}{c}2,640 \\
(500-8,150)\end{array}$ & $\begin{array}{c}1,808 \\
(450-4,900)\end{array}$ & $\begin{array}{c}32 \% \\
26(13-37)\end{array}$ \\
\hline $\begin{array}{l}\mathrm{N}^{\circ} 5(\mathrm{n}=26) \\
\text { Argentina thoroughbreds }\end{array}$ & $\begin{array}{c}2,376 \\
(550-4,900)\end{array}$ & $\begin{array}{c}1,162 \\
(150-3,850)\end{array}$ & $\begin{array}{c}51 \% \\
42(22-59)\end{array}$ \\
\hline
\end{tabular}

* arithmetic average and ** range.

Table IV. - Faecal egg count reduction test after treatment (FECR based on D12, 12 days) in five stables of Raf-2 after thiabendazole treatment using a unique dose of $18.75 \mathrm{~g}$ per horse which corresponded to $26-55 \mathrm{mg} / \mathrm{kg}$ body weight depending on horse (1999).

\begin{tabular}{|c|c|c|c|c|}
\hline Sites & No of horses & $\begin{array}{c}\text { Eggs per gram } \\
\text { D0 }\end{array}$ & $\begin{array}{l}\text { Eggs per gram } \\
\text { D10 }\end{array}$ & $\begin{array}{c}\text { FECR }(\%, \text { average or individually } \\
\text { based-with } 95 \% \\
\text { confidence interval) }(\%)\end{array}$ \\
\hline $\begin{array}{c}\text { Raf-Unit } 2 \\
50 \mathrm{mg} / \mathrm{kg}, 1999\end{array}$ & 10 & $\begin{array}{c}2,340^{*} \\
(600-10,250)^{* * *}\end{array}$ & $\begin{array}{c}1,965 \\
(450-9,500)\end{array}$ & $\begin{array}{c}16 \\
17(10-41)\end{array}$ \\
\hline $\begin{array}{c}\text { Raf-Unit } 2 \\
100 \mathrm{mg} / \mathrm{kg}, 1999\end{array}$ & 10 & $\begin{array}{c}2,815 \\
(900-8,150)\end{array}$ & $\begin{array}{c}1,430 \\
(0-4,150)\end{array}$ & $\begin{array}{c}49 \\
43(20-65)\end{array}$ \\
\hline $\begin{array}{c}\text { Raf-Unit } 2 \\
100 \mathrm{mg} / \mathrm{kg}, 2002\end{array}$ & 10 & $\begin{array}{c}3,780 \\
(300-8,700)\end{array}$ & $\begin{array}{c}1,785 \\
(150-440)\end{array}$ & $\begin{array}{c}53 \\
52(34-68)\end{array}$ \\
\hline
\end{tabular}

* arithmetic average and ** range.

Table V. - Faecal egg count reduction test (FECR) after treatment with thiabendazole in horses from two sites $(50 \mathrm{mg}-100 \mathrm{mg} / \mathrm{kg}$ body weight) (1999-2002). 
the practice is to give the same amount of drug to horses of diverse weights, which correspond to 26$55 \mathrm{mg}$ dosage/ $\mathrm{kg}$ body weight. The low efficacy was either due to low dosage or resistance. The average reductions at 50 and $100 \mathrm{mg} / \mathrm{kg}$ body weight were indicative of resistance. The lethal dose that inhibited the egg development in vitro was high in Raf-2 in 1999: $0.42 \mu \mathrm{g} / \mathrm{mL}$ compared to the $0.06 \mu \mathrm{g} / \mathrm{mL}$ of the susceptible El Harka strongyle community.

\section{DISCUSSION}

T The horse stables we choose were often dedicated to a unique or nearly unique scheme of anthelmintic treatments for the last ten years. Lack of efficacy was then expected due to repeated use of the same anthelminthic and to the repeated introductions of new horses from other countries (Europe or Argentina) where resistance to benzimidazoles is a very common feature. The helminth control practices are not that much different from Europe (O'Meara \& Mulcahy, 2002 in Ireland); the worming interval is somewhat larger (twice a year which represents $28 \%$ of parasite control in Ireland) and the drug rotation is lower (rapid-59\% or annual- $13 \%$ of horse stables) in Morocco conditions. The intensity of treatments is also lower than that recorded in South Africa (Matthee et al., 2002), five times per year in adult horses; an average of 3.4 different drugs were used annually which is not the case in Morocco (one in most cases or two different drugs per year). Morocco is then a candidate for resistance in stud or leisure horses.

The extent of resistance in horse nematodes throughout the world is recognized, particularly for benzimidazoles (Conder\& Campbell, 1995; Kaplan, 2002) which were used from 1960's. Resistance to benzimidazoles is common in horses (Dorny et al., 2000; Fisher et al., 1992; Varady et al., 2000; Woods et al., 1998, and see review by Kaplan, 2002) as it has been used for decades (Uhlinger, 1992). Resistance to benzimidazole in horses cyathostoms is then recorded for the first time in Morocco and Africa (South Africa excluded), which was expected when considering pro and cons for building up of resistance. It might be a case of introduced resistance if we consider the introductions of horses harbouring resistant worms from Argentina (Tolosa et al., 1999) or Europe (see Kaplan for review, 2002). The selective pressure remained low but permanent (the Raf-1 or Raf- 2 cases) and it probably helped the diffusion of introduced resistant genes in nematodes. The introduction of resistant worms as a major factor is the most probable hypothesis.

Although pyrantel pamoate has been used since the 1970 's, it is only in recent years that reports of resis- tance are available in United States, Norway and Denmark (in Kaplan, 2002) or Italy (Genchi et al., 1992). The first record of resistance to pyrantel pamoate in Morocco is acknowledged, in a situation where intensive use of the drug and limited introduction of infected horses is the rule. This resistance is probably of local origin due to selective pressure for many years. This again is the first record of resistance to pyrantel pamoate in Africa, outside South Africa.

The repeated use of dichlorvos did not result into selection of resistant nematodes; and no others records worldwide are indicative of resistance.

Resistance of sport or stud horse nematodes (mostly small strongyles) to anthelmintics in Morocco is already present. The small strongyle resistant species should be identified in future. The present investigation was dedicated to horses with a good environment and investigations in ordinary small holder horses should be undertaken, in order to see if resistance remained within sport/leisure horses or invaded common horses and donkeys.

\section{ACKNOWLEDGEMENTS}

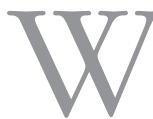

e thank the staff of veterinary services of the national Stud-farms of Bouznika and Meknes as well as the Army Forces (Raf-1 and Raf-2).

The help of Dr A. Bouchiba is gratefully acknowledged. We are also grateful to the veterinary students (R. Boukhris and A. Nouhi) who participated in the surveys. The financial support through PRAD (FranceMorocco programmes: 2001-2004) or PRFI (Morocco) helped organizing practically the investigations.

\section{REFERENCES}

Bauer C., Merkt J.C., Janke-Grimm G. \& Bürger H.J. Prevalence and control of benzimidazole-resistant small stongyles on German thoroughbred studs. Veterinary Parasitology, 1986, 21, 189-203.

Berrag B. \& El Kohen M. Parasitisme et maladies parasitaires des chevaux au Maroc. Bulletin Bimestriel Maghrebin de l'élevage et des courses de chevaux, 1999, 18, 7-10.

Bjorn H., Sommer C., Schougard H., Henriksen SA. \& NanSEN P. Resistance to benzimidazole anthelminthics in small strongyles (Cyathostominae) of horses in Denmark. Acta Veterinaria Scandinavica, 1991, 32, 253-260.

Borgsteede F.H., Roos MH., Smith G. \& Prichard R.K. Anthelminthics resistance. Veterinary Parasitology, 1996, 64, 129-132.

Cabaret J., Berrag B. \& Mrabet A. Diagnostic de la résistance anti-helminthique par les mesures de la réduction de l'excrétion des oufs dans les matières fécales : évaluation par des ré-échantillonnages. Résivers 1.0. http://www.tours.inra.fr/ sfpar/stat.htm (in French and English) 2001. 
Cabaret J. \& Berrag B. Faecal egg count reduction test for assessing anthelmintic efficacy: average versus individually based estimations. Veterinary Parasitology, 2004, 121, 105-113.

Cabaret J. \& Pandey V.S. Strongyles of the large intestine of donkeys in Morocco, with reference to the caecal strip technique of examination. Revue de Médecine Vétérinaire, 1980, 131, 405-408

Coles G.C., Bauer C., Borgsteede F.H., Geerts S., Klei T.R., TAYLOR M.A. \& WALleR P.J. World association for the advancement of Veterinary parasitology (WAAVP) methods for the detection of anthelmintic resistance in nematodes of veterinary importance. Veterinary Parasitology, 1992, 44, 35-44.

Conder G.A. \& CAmpbell W.C. Chemotherapy of nematode infections of veterinary importance, with special reference to drug resistance. Advances in Parasitology, 1995, 35, 184 .

Dorny P., Meijer I., Smets K. \& Vercruysse J. A survey of anthelminthic resistance on Belgian horse farm. Vlaams Diergeneeskunde Tijdschrift, 2000, 69, 334-337.

Drudge J.H. \& Elam G. Preliminary observations on the resistance of the horse strongyles to phenothiazine. Journal of Parasitology, 1961, 47, 38-39.

DRUDGE J.H. \& LYONS E.T. Newer development in helminth control and Strongylus vulgaris research, in: $11^{\text {th }}$ Annual meeting of the American Association Equine Practitioners, Miami Beach, Florida, 1965, 381-389.

Fisher M.A., Jacobs D.E., Grimshaw W.T. \& GibBons L.M. Prevalence of benzimidazole-resistance in equine cyathostomes populations in south-east England, Veterinary Research, 1992, 130, 315-318.

GEERTS S. Anthelminthics resistance in gastrointestinal nematodes in domestic animals. Verhandelingen- Koninklijke Academie voor Geneeskunde van Belgie, 1995, 57, 351-369.

Genchi C., Di Sacco B., Traldi G., Nogara B. \& Quintavalla E. Prime osservazioni in Italia sulla resistenza dei piccoli strongili del cavallo (Cyathostominae) ai benzimidazoli ed efficacia del pirantel pamoato. Ippologia, 1992, 3, 77-80.

KAPLAN R.M. Anthelminthic resistance in nematodes of horses. Veterinary Research, 2002, 33, 491-507.

Lyons E., Tolliver S. \& Drudge J. Historical perspective of cyathostoms: prevalence, treatment and control programs. Veterinary Parasitology, 1999, 85, 97-112.

Matthee S., Krecek C.R. \& Milne A.S. Prevalence and biodiversity of helminth parasites in donkeys from South Africa. Journal of Parasitology, 2000, 86, 756-762.

Matthee S., Dreyert FH, Hoffmann W.A. \& Van Nierkerk F.E. An introductory survey of helminth control practices in South Africa and anthelmintic resistance on thoroughbred stud farms in the Western Cape Province. Journal of the South African Veterinary Association, 2002, 73, 195-200.

MANUAL OF VETERINARY PARASITOLOGY LABORATORY TECHNIQUES. Ministry of Agriculture, Fisheries and Food, 1986, MAFF Reference Book 418, 159 p.

O'Meara B. \& Mulcahy G. A survey of control practices in equine establishments in Ireland. Veterinary Parasitology, 2002, 109, 101-110.
Ouhelli H., Cabaret J., Pandey V.S. \& Khalfane A. Localisation des parasites dans l'estomac du cheval de la région de Settat (Maroc). Revue d'Élevage et de Médecine Vétérinaire des Pays Tropicaux, 1979, 32, 347-352.

PANDEY V.S. \& CABARET J. Stomach parasites of donkeys in Morocco: habitat and interspecific interactions. Veterinary Parasitology, 1993, 49, 331-337.

PANDEY V.S. \& DAKKAK A. Les principales helminthiases des Equidés au Maroc. Traitement et prophylaxie. Maroc vétérinaire, 1979, 4, 14-23.

Pereira M.C., KoheK Junior I., CAmpos R., Lima SB. \& Foz R.P. A field evaluation of anthelminthics for control of cyathostomes of horses in Brazil. Veterinary Parasitology, 1991, 38, 121-129.

Raymond M. Présentation d'un programme Basic d'analyse log-probit pour micro-ordinateur. Cahiers ORSTOM, Série Entomologie Médicale et Parasitologie, 1985, 23, 117-121.

SAngster N. Pharmacology of anthelminthic resistance. Parasitology, 1996, 113, 5201-5206.

Silvestre A., Leignel V., Berrag B., Gasnier N., Humbert J.F., Chartier C. \& CABAret J. Sheep and goat nematode resistance to anthelmintics: pro and cons among breeding management factors. Veterinary Research, 2002, 33, 465480.

Tolosa J.S., Chiaretta A., Sanchez J. \& Munoz Cobenas M.E. Parasitosis de los equinos. Una actualizacion sobre su etiopatogenia y su control. Universidad Rio Cuarto/Fort Dodge, 1999, $82 \mathrm{p}$.

Uhlinger C.A. \& Kristula M. Effects of alternation of drug classes on the development of oxibendazole resistance in a herd of horses. Journal of the American Veterinary Medicine Association, 1992, 201, 51-55.

VARAdy M., Konigova A. \& Corba J. Benzimidazole resistance in equine cyathostomes in Slovakia. Veterinary Parasitology, 2000, 94, 67-74.

WALLER P.J. Control strategies to prevent resistance. Veterinary Parasitology. 1993, 46, 133-142.

Woods T.F., Lane T.J., Zeng Q.Y. \& Courtney C.H. Anthelminthic resistance on horse farms in north central Florida. Equine Practice, 1998, 20, 14-17.

Reçu le 19 juillet 2005 Accepté le 4 août 2005 